\title{
Development of One-Step Reverse Transcriptase-Polymerase Chain Reaction to Detect Duck Hepatitis Virus Type 1
}

\author{
Min-Chul Kim, ${ }^{\mathrm{A}}$ Yong-Kuk Kwon, ${ }^{\mathrm{A}}$ Seong-Joon Joh, ${ }^{\mathrm{A}}$ Jun-Hun Kwon, ${ }^{\mathrm{A}}$ Jae-Hong Kim, ${ }^{\mathrm{A}}$ and Sun-Joong Kim ${ }^{\mathrm{BC}}$ \\ ${ }^{A}$ National Veterinary Research and Quarantine Service, 480 Anyang 6 dong, Manan-gu, Anyang, Gyeonggi-do, 420-824, Republic of Korea \\ ${ }^{\mathrm{B}}$ College of Veterinary Medicine, Seoul National University, Seoul, 151-742, Republic of Korea
}

Received 3 October 2006; Accepted 25 November 2006

\begin{abstract}
SUMMARY. A one-step reverse transcriptase-polymerase chain reaction (RT-PCR) method was developed and optimized for the detection of duck hepatitis virus type 1 (DHV-1) using the Viral Gene-spin ${ }^{\mathrm{TM}}$ viral DNA/RNA extraction kit. A pair of DHV1 -specific primers was designed against the gene encoding RNA-dependent RNA polymerase (3D gene). Using RNA prepared from duckling liver samples infected with two reference and seven Korean field isolates of DHV-1, one-step RT-PCR with DHV1-specific primers amplified a 467-bp fragment. Under the same conditions, no amplification was observed for 14 other avian pathogenic viruses and bacteria. Using RNA prepared from serial dilutions of the DHV-1 with the supernatant of the uninfected duckling liver homogenate $(10 \% \mathrm{w} / \mathrm{v})$, the one-step RT-PCR assay was found to be sensitive to $1050 \%$ egg lethal dose $\left(\mathrm{ELD}_{50}\right)$ $0.1 \mathrm{ml}^{-1}$ of DHV-1. Furthermore, this method detected DHV-1 from the livers and allantoic fluid of duck embryos dying before 3 days postinoculation (PI) and of chicken embryos that were chilled at 3 days PI. Therefore, this one-step RT-PCR method is rapid, sensitive, and reliable, and can be readily adapted for detection of DHV-1 from other clinical samples.
\end{abstract}

RESUMEN. Desarrollo de una prueba de reacción en cadena por la polimerasa transcriptasa reversa de un solo paso para detectar virus de hepatitis de los patos tipo 1.

Se desarrolló y optimizó una prueba de reacción en cadena por la polimerasa transcriptasa reversa de un solo paso para la detección del virus de hepatitis de los patos tipo 1, utilizando para ello el paquete de extracción de ADN y ARN viral Vital Gene$\operatorname{spin}^{\mathrm{TM}}$. Se diseñó un par de iniciadores específicos para el virus de hepatitis de los patos tipo 1 dirigidos al gen que codifica para la polimerasa ARN dependiente de ARN. Utilizando ARN proveniente de muestras de hígado de patos infectados con dos cepas de referencia y siete aislamientos de campo del virus de hepatitis de los patos tipo 1 provenientes de Corea, la prueba de reacción en cadena por la polimerasa transcriptasa reversa de un solo paso amplificó un fragmento de 467 pares de bases. Bajo las mismas condiciones, no se observó amplificación de otros 14 virus y bacterias patógenos para las aves. Utilizando ARN proveniente de diluciones seriadas del virus de hepatitis de los patos tipo 1 preparadas con el sobrenadante de homogenizados de hígado de patos no infectados (10\% agua/volumen), se determinó que la prueba de reacción en cadena por la polimerasa transcriptasa reversa de un solo paso es sensible hasta 10 dosis letal $50 \%$ para embrión por mililitro del virus de hepatitis de los patos tipo 1 . Más aun, este método detectó virus de hepatitis de los patos tipo 1 de los hígados y fluido alantoideo de embriones de pato muertos tres días posteriores a la inoculación y embriones de pollo que fueron enfriados tres días posteriores a la inoculación. En consecuencia, este método de reacción en cadena por la polimerasa transcriptasa reversa de un solo paso es rápido, sensible y confiable y puede ser adaptado rápidamente para la detección del virus de hepatitis de los patos tipo 1 de diferentes muestras clínicas.

Key words: duck hepatitis virus (DHV) type 1 (DHV-1), one-step RT-PCR, RNA-dependent RNA polymerase

Abbreviations: $\mathrm{AEV}=$ avian encephalomyelitis virus; $\mathrm{AIV}=$ avian influenza virus; $\mathrm{ATCC}=$ American Type Culture Collection; $\mathrm{DH}=$ duck hepatitis; $\mathrm{DHV}=$ duck hepatitis virus; DHV-1 = duck hepatitis virus type 1; ELD = embryo lethal dose; $\mathrm{IBDV}=$ infectious bursal disease virus; IBV = infectious bronchitis virus; LTV = laryngotracheitis virus; NDV = Newcastle disease virus; $\mathrm{nt}=$ nucleotide; $\mathrm{PBS}=$ phosphate-buffered saline; $\mathrm{PI}=$ postinoculation; $\mathrm{RT}$-PCR $=$ reverse transcriptase-polymerase chain reaction; $\mathrm{SPF}=$ specific-pathogen free; $\mathrm{UTR}=$ untranslated region

Duck hepatitis $(\mathrm{DH})$ is a frequently fatal, rapidly spreading viral infection of young ducklings, and can be caused by duck hepatitis virus (DHV) types 1,2 or 3 (29). DHV type 1 (DHV-1) is worldwide in distribution and has been isolated from the livers of infected ducklings since the first outbreak in 1949 on Long Island, New York (14). Duck hepatitis is of economic importance to duckraising farms because of the potential high mortality from uncontrolled infection. New isolates of DHV were identified in China (7) and Korea (21). Since the occurrence of duck viral hepatitis in ducklings was first reported in Korea it has continued to occur.

The genomic sequences reported in this paper have been submitted to GenBank and assigned the following accession numbers: DHV type 1 strain DRL-62 (GenBank DQ219396), DHV type 1 strain R85952 (GenBank DQ226541), AP-03337 (GenBank DQ256132), and AP-04203 (GenBank DQ256134).

${ }^{\mathrm{C}}$ Corresponding author. E-mail: kimsja@snu.ac.kr
Young ducklings infected with DHV-1 exhibit the following clinical signs: they are lethargic; they squat down with their eyes partially closed; they fall on their sides, kick spasmodically, and die with their heads drawn back. DHV-1 infection causes 100\% morbidity and although mortality varies, it may reach $95 \%$ in young ducklings less than 1 wk old, $50 \%$ or less in ducklings between 1 and $3 \mathrm{wk}$ of age, and negligible levels in those $4-5 \mathrm{wk}$ of age (29). Breeding ducks can be infected but show no clinical signs and continue in full production. Transmission is most easily accomplished by intramuscular injection or by feeding with egg-propagated virus or virus-infected organs. Egg transmission of DHV-1 does not occur (1).

The DHV-1 virion is estimated to be $20-40 \mathrm{~nm}$ in size (23) and, although comparatively stable at temperatures up to $45 \mathrm{C}$, is rapidly inactivated at higher temperatures. The virion is stable for $9 \mathrm{hr}$ at $\mathrm{pH} 3$, but not for $48 \mathrm{hr}$ (3) and is, therefore, classified as an enterovirus-like virus (28). Growth of DHV-1 is not inhibited in the presence of the nucleoside analog 5-bromo-2-deoxyuridine, indicating that it has an RNA genome (26). 
The presence of DHV-1 is usually confirmed either by inoculation of the isolate into susceptible ducklings or duck or chicken embryos or by inoculation of duck embryo liver cell cultures (World Organization for Animal Health, http://www.oie.int). Other diagnostics include direct fluorescence-antibody technique using the livers from naturally occurring cases or inoculated duck embryos $(15,27)$. The methods reported for the detection of anti-DHV-1 antibody in duck sera include virus neutralization $(9,30)$, agar gel diffusion precipitation (17) and enzyme-linked immunosorbent assay (33). However, these isolation and serological methods are both time consuming and labor intensive. In addition, serological tests have not been useful in diagnosing acute outbreaks of DHV-1. Therefore, in recent years, the polymerase chain reaction (PCR) has been applied as a rapid diagnostic tool for the detection of avian viral and bacterial pathogens $(16,18,19,25,31,32)$.

DHV-1 was included in the unassigned viruses in the Picornaviridae (International Committee on the Taxonomy of Viruses, http://www.ncbi.nlm.nih.gov/ICTVdb/). Recently, however, the genomes of DHV-1s, DRL-62 and R85952, were fully sequenced and the polyprotein organization of the $\mathrm{DHV}-1 \mathrm{~s}$ was NH2-VP0-VP3-VP1-2A1-2A2-2B-2C-3A-3B-3C-3D-COOH (10). It has previously been shown that the structural proteins coded by the amino-terminal part of the polyprotein are suitable for phylogenetic analyses within genera, species, or serotypes whereas the nonstructural proteins are conserved during evolution. The $3 \mathrm{D}$ and $2 \mathrm{C}$ genes and corresponding proteins are two of the mostconserved proteins among the Picornaviridae and are therefore frequently used for phylogenetic analysis when comparing viruses belonging to different genera within the family $(4,6,22,24)$.

In this study, a one-step reverse transcriptase-PCR (one-step RTPCR) assay using 3D gene-specific primers to detect DHV-1 sequences was developed and optimized.

\section{MATERIALS AND METHODS}

Viral and bacterial propagation. The viruses and bacteria used in this study are listed in Table 1. Each liver sample of ducklings infected with two reference strains (DRL-62 and R85952) of DHV-1 obtained from the American Type Culture Collection (ATCC; Manassas, VA) for comparative purposes and each liver sample of DHV-1-infected ducklings from 2004 to 2005 was homogenized in phosphate-buffered saline (PBS, pH 7.2, 10\% w/v) containing penicillin $\mathrm{G}$ sodium salt $\left(10,000 \mathrm{IU} \mathrm{ml}^{-1}\right)$ and streptomycin sulfate salt $\left(100 \mu \mathrm{g} \mathrm{ml}^{-1}\right)$ (SigmaAldrich Co., St. Louis, MO). These samples were clarified by centrifugation $(2000 \times g$ at $4 \mathrm{C}$ for $20 \mathrm{~min})$ and the supernatants were used for direct one-step RT-PCR.

Embryonated specific-pathogen free (SPF) chicken eggs (Charles River SPAFAS, Inc., Dallas, IA) were inoculated with a field isolate of avian encephalomyelitis virus (AEV) at 6 days of incubation by the yolk sac route. At 11 days postinoculation (PI) the brains were sampled from the infected embryos and suspended in PBS $(10 \% \mathrm{w} / \mathrm{v})$. Brain tissues were disrupted by three cycles of freeze-thaw, followed by centrifugation at $2000 \times g$ for $30 \mathrm{~min}$; the supernatant was stored at $-70 \mathrm{C}$.

Infectious bronchitis virus (IBV), avian influenza virus (AIV), and Newcastle disease virus (NDV) were propagated in the allantoic cavities of 10-day-old SPF chicken embryos. Infectious bursal disease virus (IBDV), infectious laryngotracheitis virus (LTV), reovirus, and adenovirus were propagated on the chorioallantoic membranes in 10-day-old SPF chicken embryos. The media used for cultivation of bacteria were blood agar for Riemerella anatipestifer and Pasteurella multocida, MacConkey agar for Escherichia coli and Salmonella Enteritidis, and Frey medium (5) for Mycoplama gallisepticum and Mycoplasma synoviae.

Virus preparation for sensitivity test. The reference strain DHV-1 virus, DRL-62, was propagated in 11-day-old duck embryos. After incubation for $48 \mathrm{hr}$ at $37 \mathrm{C}$, a homogenate of the infected duck
Table 1. Avian pathogens used for one-step RT-PCR.

\begin{tabular}{lll}
\hline \multicolumn{1}{c}{ Species } & \multicolumn{1}{c}{ Strain/serotype } & \multicolumn{1}{c}{ Source } \\
\hline Duck viral hepatitis & DRL-62 (type 1) & ATCC \\
& R85952 (type 1) & ATCC \\
& Field isolate, AP-03317 & NVRQS \\
& Field isolate, AP-03337 & NVRQS \\
& Field isolate, AP-04009 & NVRQS \\
& Field isolate, AP-04092 & NVRQS \\
& Field isolate, AP-04114 & NVRQS \\
& Field isolate, AP-04203 & NVRQS \\
& Field isolate, AP-04Q6 & NVRQS \\
& Field isolate & NVRQS \\
Avian encephalomyelitis & Field isolate (H9N2) & NVRQS \\
Avian influenza virus & ATCC S1133 & NVRQS \\
Reovirus & Field isolate & NVRQS \\
Newcastle disease virus & Field isolate & NVRQS \\
Infectious bursal disease virus & Mass 41 & NVRQS \\
Infectious bronchitis virus & Field isolate & NVRQS \\
Adenovirus & Field isolate & NVRQS \\
Infecioius laryngotracheitis virus & ATCC 11845 & ATCC \\
Riemerella anatipestifer & Field isolate & NVRQS \\
Pasteurella multocida & Field isolate & NVRQS \\
Escherichia coli & Field isolate & NVRQS \\
Salmonella Enteritidis & ATCC 15302 & ATCC \\
Mycoplasma gallisepticum & ATCC 25204 & ATCC \\
Mycoplasma synoviae &
\end{tabular}

${ }^{\mathrm{A}} \mathrm{ATCC}=$ American Type Culture Collection.

${ }^{\mathrm{B}} \mathrm{NVRQS}=$ National Veterinary Research and Quarantine Service.

embryo liver was submitted to three cycles of freeze-thaw. The viral suspension was clarified by centrifugation at $2000 \times g$ for $30 \mathrm{~min}$ and the supernatant was stored at $-70 \mathrm{C}$ for the sensitivity test.

Nucleic acid extraction. Extractions of viral RNA and DNA were performed using the Viral Gene-spin ${ }^{\mathrm{TM}}$ viral DNA/RNA extraction kit (iNtRON Biotechnology, Seongnam, Korea). In brief, a total of $150 \mu \mathrm{l}$ of the sample for extraction was mixed with $250 \mu$ lysis buffer. For the RT-PCR sensitivity tests, $50 \mu \mathrm{l}$ of DEPC-treated distilled water was added to $100 \mu \mathrm{l}$ of 10 -fold virus dilution of the samples before mixing with the lysis buffer. A 350- $\mu$ l aliquot of binding buffer was added to the mixture and triturated; the total $750 \mu \mathrm{l}$ was placed into a minispin column, which was spun at room temperature for $1 \mathrm{~min}$ at 13,000 rpm in a microcentrifuge. The flow-though was discarded and two cycles of washing-spinning-flow-through-removal were performed using washing buffers A and B ( $500 \mu \mathrm{l}$ each), followed by a final spin for $1 \mathrm{~min}$ to dry the membrane. The column was transferred to a new $1.5-\mathrm{ml}$ collection tube and RNA/DNA was eluted by addition of $40 \mu \mathrm{l}$ elution buffer and centrifugation for $1 \mathrm{~min}$ at $13,000 \mathrm{rpm}$.

DNA extraction from bacteria was performed using the G-spin ${ }^{\text {TM }}$ Genomic DNA extraction kit (iNtRON Biotechnology) according to the manufacturer's instructions.

After measuring RNA or DNA concentrations using the NanoDrop ND-1000 (NanoDrop, Wilmington, DE), the samples were stored at $-20 \mathrm{C}$

Specificity and sensitivity of the DHV-1 one-step RT-PCR. Specificity of the DHV-1 one-step RT-PCR was evaluated by subjecting extracts of DNA or RNA (50 ng each) from four DHV-1 isolates (DRL62, R85952, AP-03337, and AP-04203) and 14 avian viruses and bacteria to DHV-1-specific one-step RT-PCR. For determination of the sensitivity of the test, serial dilutions (from $1 \times 10^{5}$ to $1 \times 10^{-2} 50 \%$ egg lethal dose $\left[\mathrm{ELD}_{50}\right] 100 \mu \mathrm{I}^{-1}$ ) of the virulent virus, DRL-62, were prepared from mixing with a supernatant of an uninfected duckling liver homogenate $(10 \% \mathrm{w} / \mathrm{v})$. The RNA extract prepared from the serial 10 fold dilutions were subjected to DHV-1 one-step RT-PCR.

Oligonucleotide primers. Vector NTI suite 8 program (InforMax, Frederick, MD) was used for retrieving the nucleotide (nt) sequences from the representative viruses of nine genera in the Picornaviridae (10) via the National Center for Biotechnology Information's Entrez Server. The retrieved sequences were trimmed with the Bioedit program and sequence 


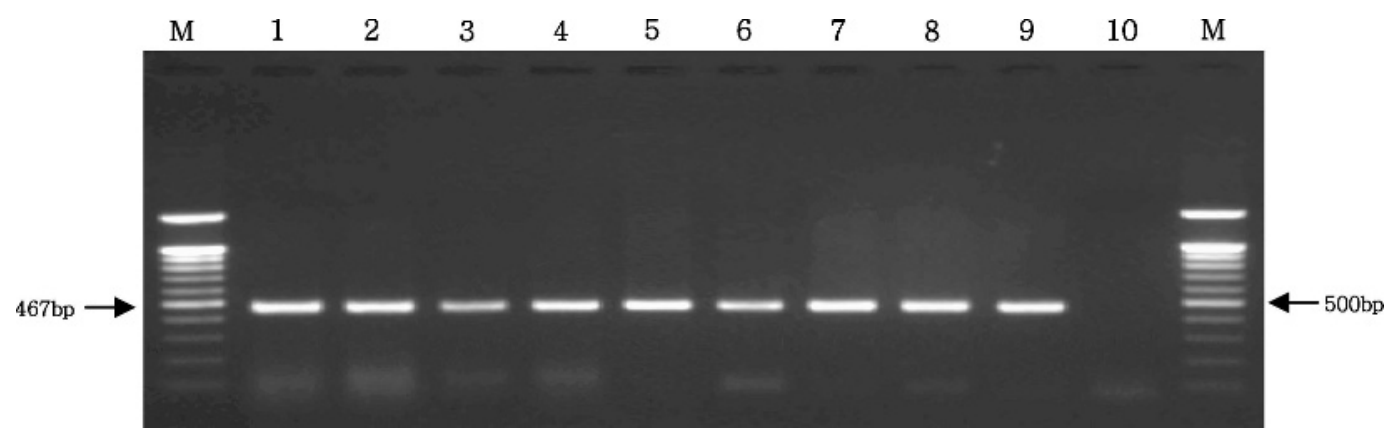

Fig. 1. Agarose gel electrophoresis of products amplified from DHV-1-infected duckling liver samples using DHV-1-specific primers and direct one-step RT-PCR. Lane M, 100-bp DNA marker; lanes 1 and 2, DHV-1 strains DRL-62 and R85952, respectively; lanes 3-9, Korean DHV-1 isolates AP-03317, AP-03337, AP-04009, AP-04092, AP-04114, AP-04203, and AP-04Q6, respectively; and lane 10, negative control (DHV-1uninfected duckling liver sample).

comparisons between three full-sequenced Korean isolates (AP-03337, AP-04009, and AP-04203), DRL-62, and R85952 and other picornaviruses were made using a sequence identity matrix in the Bioedit program (8). The nt sequences of the primers targeting the RNA-dependent RNA polymerase (3D) gene of DHV-1 were selected with the comparative analysis. The primers were designated DHV-1 ComF (5'-AAG AAG GAG AAA ATY(C or T) AAG GAA GG-3') and DHV-1 ComR (5'TTG ATG TCA TAG CCC AAS(C or G) ACA GC-3') and flanked a 467-bp DNA sequence in the 3D gene.

One-step RT-PCR. One-step RT-PCR was conducted using the Maxime RT-PCR PreMix kit (iNtRON Biotechnology). The 20- $\mu$ l reaction mixtures contained $1 \mathrm{U}$ of OptiScript reverse transcriptase, $2.5 \mathrm{mM}$ dNTPs, $2.5 \mathrm{U}$ i-StarTaq DNA polymerase, and RT-PCR buffer $(50 \mathrm{mM}$ Tris- $\mathrm{HCl}$ and $75 \mathrm{mM} \mathrm{KCl})$. In addition, the following components were included in the reaction: $4 \mu \mathrm{l}(50 \mathrm{ng})$ RNA or DNA template, $1 \mu \mathrm{l}\left(10 \mathrm{pmol}^{-1} \mathrm{l}^{-1}\right)$ of each specific primer (DHV-1 ComF and DHV-1 ComR), and DEPC-treated $\mathrm{dH}_{2} \mathrm{O}$ to a total reaction volume of $20 \mu \mathrm{l}$.

A T-gradient thermal cycler (Biometra, Gottingen, Germany) was used for one-step RT-PCR. Reverse transcription was performed at $45 \mathrm{C}$ for $30 \mathrm{~min}$, after which the enzyme was inactivated at $94 \mathrm{C}$ for $5 \mathrm{~min}$. PCR amplification was conducted using an initial denaturation for $20 \mathrm{sec}$ at $94 \mathrm{C}$; followed by 40 cycles of annealing for $30 \mathrm{sec}$ at $52 \mathrm{C}$, extension for $30 \mathrm{sec}$ at $72 \mathrm{C}$, and denaturation for $20 \mathrm{sec}$ at $94 \mathrm{C}$; and a final extension for $5 \mathrm{~min}$ at $72 \mathrm{C}$. Reactions were stored at $4 \mathrm{C}$.

Detection of DHV-1 from duck and chicken embryo organs. Supernatants prepared from duckling livers infected with DHV-1 of seven different Korean isolates and two reference strains were collected and filtered $(0.2 \mu \mathrm{m})$. The allantoic cavities of each five 11-day-old duck and 9-day-old chicken embryonated eggs were inoculated with $0.2 \mathrm{ml}$ viral supernatant. The allantoic fluids and liver samples were collected from the embryos inoculated with two reference strains and seven
Korean isolates, both dead and alive, at 3 days PI. Each liver sample was ground in a tissue grinder and PBS was added to make $10 \%$ suspensions. Liver sample suspensions and allantoic fluid were centrifuged at $2000 \times$ $g$ for 30 min, the supernatants treated with the Viral Gene-spin ${ }^{\text {TM }}$ viral DNA/RNA extraction kit and the nucleic acids used for one-step RTPCR.

Detection of one-step RT-PCR products. PCR products $(10 \mu \mathrm{l})$ were separated by electrophoresis $(100 \mathrm{~V})$ in horizontal $1.5 \%$ agarose gels (iNtRON Biotechnology) and Tris-acetate buffer ( $40 \mathrm{mM}$ Trisacetate, $1 \mathrm{mM}$ ethylenediamine tetraacetic acid). Gels were stained with ethidium bromide $\left(0.5 \mathrm{ug} \mathrm{ml}^{-1}\right)$, visualized under ultraviolet light, and photographed.

Accession numbers of DHV-1 sequences submitted to GenBank. The DHV-1 sequences used for one-step RT-PCR in this study were sequenced and submitted to GenBank and assigned the following accession numbers: DHV type 1 strain DRL-62 (DQ219396), DHV type 1 strain R85952 (DQ226541), AP-03337 (DQ256132), AP04009 (DQ256133), and AP-04203 (DQ256134).

\section{RESULTS}

Comparative analysis for primer design. Two untranslated regions and 11 protein genes between three Korean isolates and two standard strains of DHV-1 were analyzed. The nt identities in three Korean isolates were more than $98 \%$. The identities between three Korean isolates and two standard strains were between $57 \%$ nt identity in $3^{\prime}$ untranslated region (UTR) and $80 \%$ nt identity in the $2 \mathrm{~B}$ gene. Although the $2 \mathrm{~B}$ gene shared the most identity between three Korean isolates and two standard strains, the 3D gene was selected for optimal primers with $76 \%$ nt identity because of the target gene length, optimal product size, and greater analysis in

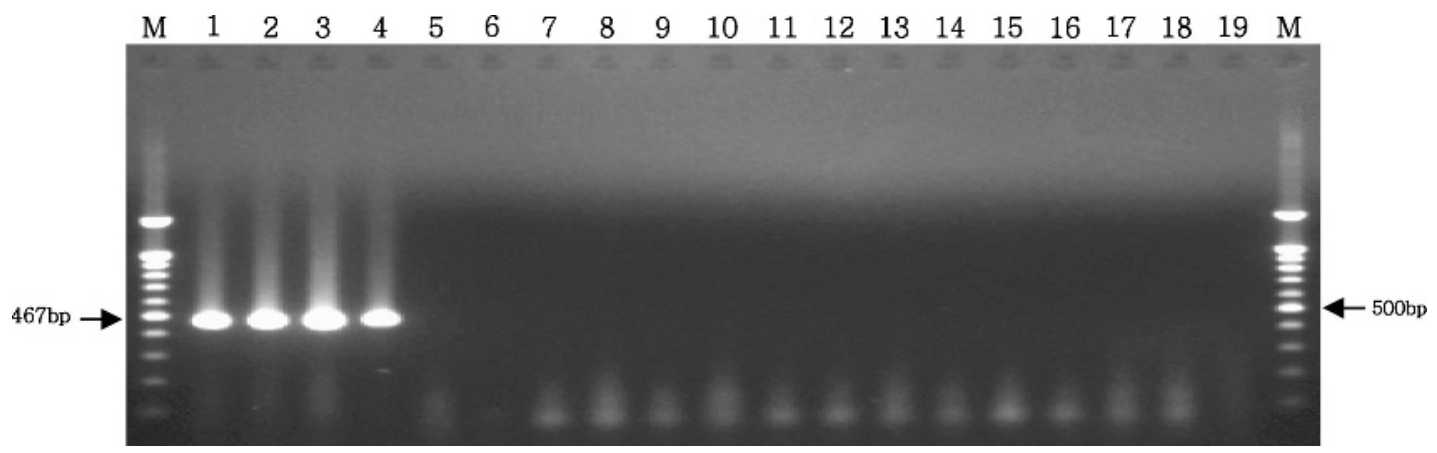

Fig. 2. Agarose gel electrophoresis of products amplified using DHV-1-specific primers and direct one-step RT-PCR. Lane M, 100-bp DNA marker; lanes 1 and 2, DHV-1 strains DRL-62 and R85952, respectively; lanes 3 and 4, Korean DHV-1 isolates AP-03337 and AP-04203, respectively; lanes 5-18, AEV, reovirus, AIV, NDV, IBV, IBDV, adenovirus, LTV, $R$ anatipestifer, P. multocida, E. coli, Salmonella Enteritidis, M. gallisepticum, and M. synoviae, respectively; and lane 19, negative control (DHV-1-uninfected duckling liver sample). 


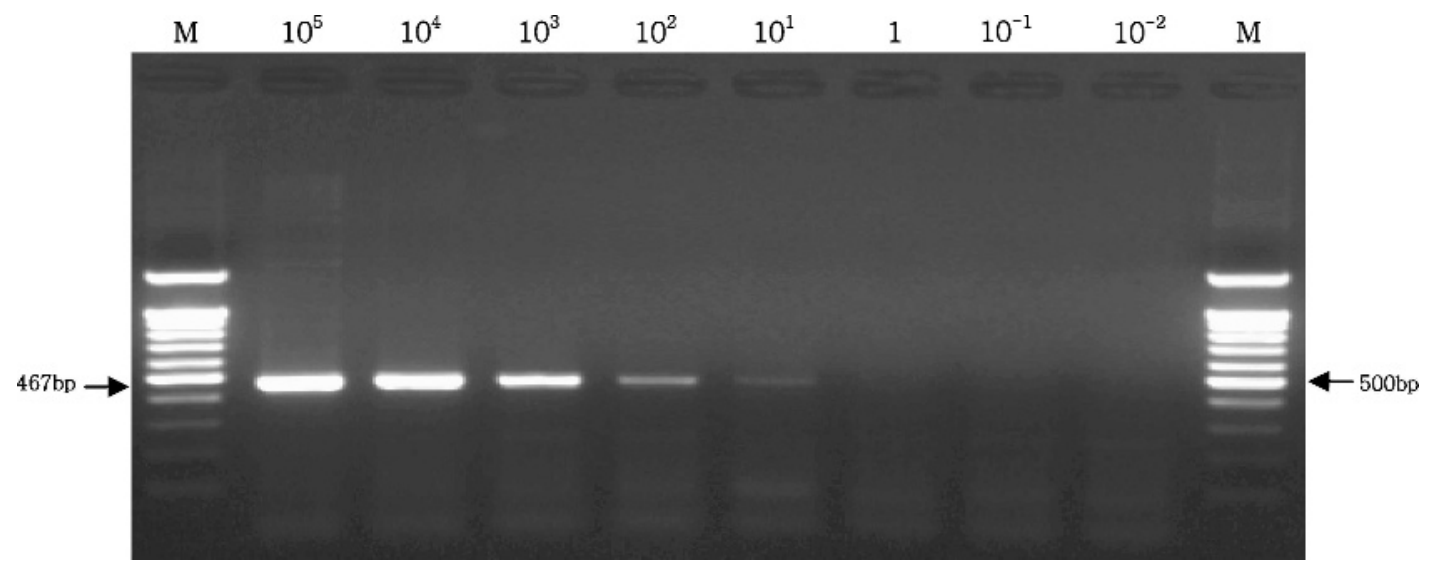

Fig. 3. Agarose gel electrophoresis of one-step RT-PCR amplification of RNA prepared from serial dilutions of DHV-1-infected liver homogenates. Lane M, 100-bp DNA marker; one-step RT-PCR amplification of RNA prepared from serial dilutions of DHV-1 ranging from $10^{5}$ to $10^{-2} \mathrm{ELD}_{50} 100 \mu \mathrm{l}^{-1}$.

picornaviruses. Comparative analysis of the 3D gene between duck hepatitis viruses and other picornaviruses showed that the nt identity was less than $37 \%$ and that the $3 \mathrm{D}$ gene is proper for the specific DHV-1 primers.

One-step RT-PCR amplification. As expected, a DNA fragment of 467 bp was amplified by one-step RT-PCR using RNA extracted from the livers of ducklings infected with seven Korean and two reference DHV-1 strains (Fig. 1, lanes 1-9). The negative control RNA was obtained from an uninfected duckling liver and did not amplify under the same conditions (Fig. 1, lane 10).

Specificity of the DHV-1 one-step RT-PCR. One-step RT-PCR amplified a DNA fragment of 467 bp from DHV-1 RNA of two reference strains (DRL-62 and R85952; Fig. 2, lanes 1 and 2) and two Korean isolates (AP-03337 and AP-04203; Fig. 2, lanes 3 and 4). Under the same conditions, no amplification occurred using nucleic acids from 14 other avian pathogens (RNA from AEV, AIV, IBV, IBDV, NDV, and reovirus and DNA from adenovirus, LTV, E. coli, M. gallisepticum, M. synoviae, P. multocida, R. anatipestifer and Salmonella Enteritidis; Fig. 2, lanes 5-18).

Sensitivity of one-step RT-PCR for DHV-1. The sensitivity of DHV-1 detection was investigated using nucleic acids prepared with the Viral Gene-spin ${ }^{\text {TM }}$ viral DNA/RNA extraction kit, followed by amplification with one-step RT-PCR. Using the Viral Gene-spin extraction method, DHV-1 RNA was extracted from the serial dilutions (from $1 \times 10^{5}$ to $1 \times 10^{-2} \mathrm{ELD}_{50} 100 \mu \mathrm{l}^{-1}$ ) of the virulent virus, DRL-62, followed by one-step RT-PCR. The limit

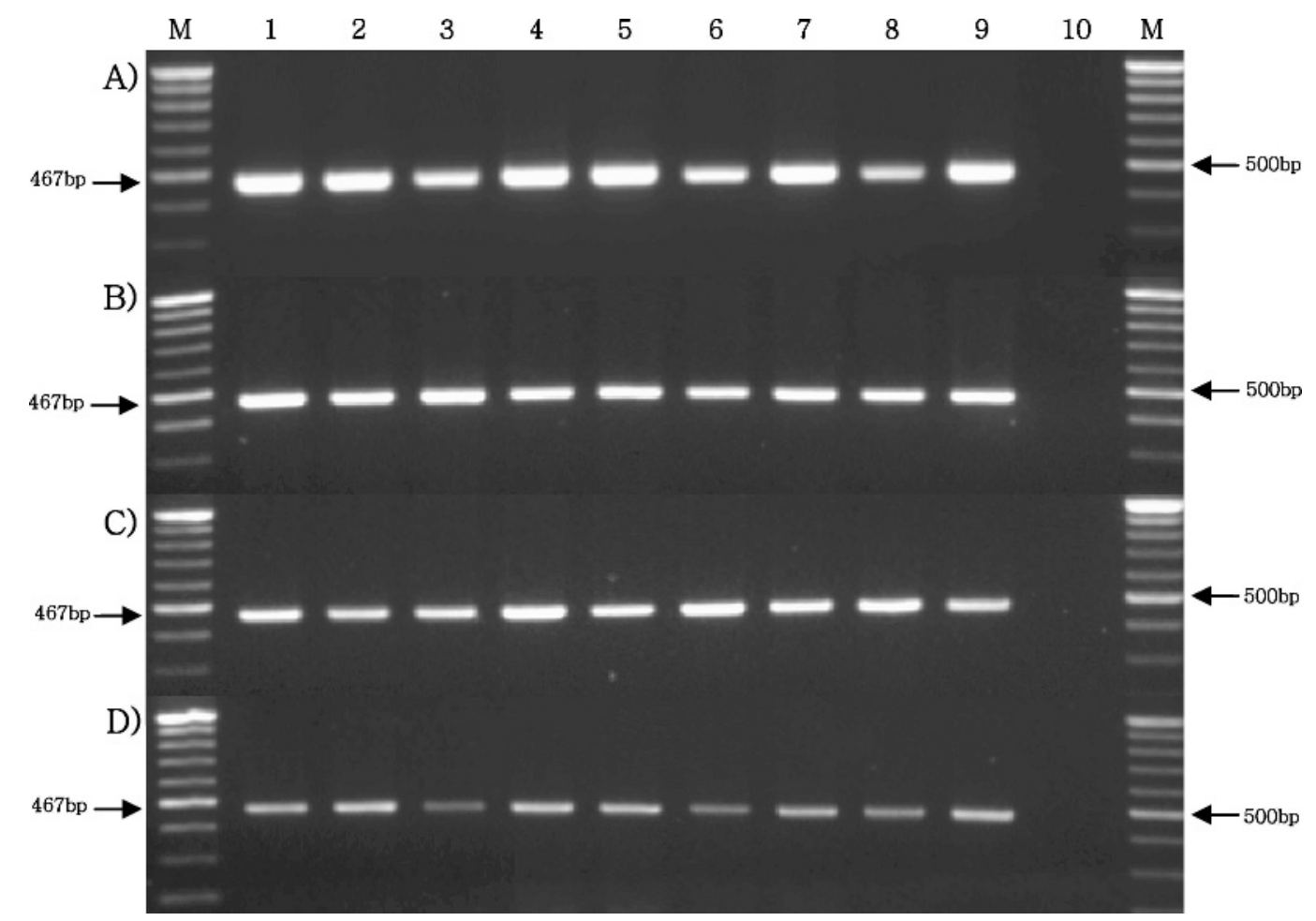

Fig. 4. Agarose gel electrophoresis of DHV-1 one-step RT-PCR products from duck embryo livers (A) and allantoic fluid (B) and chicken embryo livers (C) and allantoic fluid (D). Lane M, 100-bp DNA marker; lanes 1 and 2, DHV-1 strains DRL-62 and R85952, respectively; lanes 39, Korean DHV-1 isolates AP-03317, AP-03337, AP-04009, AP-04092, AP-04114, AP-04203, and AP-04Q6, respectively; and lane 10, negative control (DHV-1-uninfected duck embryo liver or allantoic fluid). 
of sensitivity for detection of DHV-1 in the supernatant of duckling liver homogenate was $10 \mathrm{ELD}_{50}$ (Fig. 3). The one-step RT-PCR assay was found to be sensitive to $10 \mathrm{ELD}_{50} 0.1 \mathrm{ml}^{-1}$ of DHV-1.

Detection of DHV-1 from duck and chicken embryos. Seven different supernatants were obtained from allantoic fluid and 10\% liver tissue suspensions of duck embryos that died before 3 days PI and chicken embryos that were chilled at 3 days PI. DHV-1 onestep RT-PCR amplified a single 467-bp fragment from all infected duck and chicken embryos and liver and allantoic fluid samples (Fig. 4). The negative controls (uninfected duck embryo liver and allantoic fluid) were not amplified under the same conditions.

\section{DISCUSSION}

DHV-1 has been a recognized duckling pathogen since the virus was first isolated (14). Conventional DHV-1 diagnosis is timeconsuming, based as it is on virus isolation from duckling liver samples or cell culture, followed by identification via a neutralization test using DHV-1 specific serum. However, because the DHV-1 genome has now been sequenced, molecular detection techniques such as RT-PCR can be applied. Here, the complete DHV-1 nt sequences from two reference strains (DRL-62 and R85952) and three Korean isolates (AP-03337, AP-04009, and AP-04203) were determined and submitted to GenBank. Pairwise comparison of the DHV-1 polyprotein sequences of two reference strains with representatives from each genus of the Picornaviridae family indicated that it was most closely related to Ljungan virus of the genus Parechovirus but that the two reference DHV-1 strains including three Korean isolates form a monophyletic group, clearly distinct from members of the genus Parechovirus (data not shown) (10).

The principal objective of this study was to develop a one-step RT-PCR method that enabled rapid, sensitive, specific, and simple detection of DHV-1 RNA. Using the Viral Gene-spin ${ }^{\text {TM }}$ viral DNA/RNA extraction kit, DHV-1 RNA from infected tissues obtained from the livers of ducklings and the livers and allantoic fluid of duck and chicken embryos was prepared. One-step RT-PCR was then performed on the RNA, using primers designed against DHV-1 3D sequence.

Traditionally, RNA has been prepared by lysing cells in guanidinium thiocyanate in the presence of detergent, followed by phenol-chloroform extraction and ethanol precipitation. That method is both time-consuming and necessitates removal of several reagents that can interfere with RT-PCR, such as salts and traces of detergent or phenol. Extraction of viral DNA and RNA using spin columns does not involve cumbersome and time-consuming extraction or precipitation procedures, and does not require the use of toxic preparatory chemicals. Therefore, the Viral Genespin $^{\text {TM }}$ viral DNA/RNA extraction kit for preparation of viral RNA or DNA was used. In addition, the standard RT-PCR reaction is performed in two separate steps, potentially increasing the risk of contamination. Thus, one-step RT-PCR, which requires less handling of the sample, is less labor-intensive, and less prone to contamination.

The sequences of structural proteins (VP1 to VP4) in the amino terminal region of the Picornaviridae polyprotein are suitable for phylogenetic analyses within genera, species, or serotypes whereas the nonstructural proteins have been conserved: the $3 \mathrm{D}$ and $2 \mathrm{C}$ proteins represent two of the most highly conserved proteins among the Picornaviridae (6). Thus, the amino acid sequences of the $3 \mathrm{D}$ and
2C proteins are used frequently for phylogenetic analyses between members of the family belonging to different genera $(4,6,22,24)$. A pair of primers against the gene encoding RNA-dependent RNA polymerase (the 3D gene) was designed using the DHV-1 genomic sequence data submitted to GenBank. One-step RT-PCR amplified a 467-bp DNA band from all RNA prepared from tissues infected with different strains of DHV-1. In contrast, RNA from uninfected duckling liver samples and RNA or DNA from other avian pathogens was not amplified under the same conditions (Figs. 1, 2). Primers specific to each virus (AEV (32); AIV (12); adenovirus, IBDV, and reovirus (2); NDV (11); and IBV (13)) amplified the respective nucleic acid using one-step RT-PCR (data not shown). The sensitivity of DHV-1 detection was evaluated using duck embryo liver homogenate samples, and was found to be $10 \mathrm{ELD}_{50}$ $100 \mu \mathrm{l}^{-1}$ (Fig. 3). These results confirmed the specificity and sensitivity of one-step RT-PCR of DHV-1.

Investigation of DHV-1-infected duck and chicken embryos revealed that there is a sufficient viral load for detection of DHV-1 in 11-day-old duck embryo livers and in allantoic fluid before 3 days PI, and in 9-day-old chicken embryo livers and allantoic fluid at 3 days PI (Fig. 4). These results may be because of the ease with which DHV-1 can propagate in these embryos.

In summary, a rapid, sensitive, and specific diagnostic for DHV-1 infection is required, because currently clinical diagnoses of DHV-1 infection are made by virus isolation and immunological detection methods that are laborious and time-consuming. In this study, a onestep RT-PCR method, which was simple, sensitive, and specific, was optimized.

\section{REFERENCES}

1. Asplin, F. D. An attenuated strain of duck hepatitis virus. Vet. Rec. 70:1226-1230. 1958.

2. Caterina, K. M., S. Frasca Jr., T. Grishick, and M. I. Khan. Development of a multiplex PCR for detection of avian adenovirus, avian reovirus, infectious bursal disease virus and chicken anemia virus. Mol. Cell. Probes 18:293-298. 2004.

3. Davis, D. Temperature and $\mathrm{pH}$ stability of duck hepatitis virus. Avian Pathol. 16:21-30. 1987.

4. Domingo, E., M. G. Mateu, C. Escarmis, E. Martinez-Salas, D. Andreu, E. Giralt, N. Verdaguer, and I. Fita. Molecular evolution of aphthoviruses. Virus Genes 11:197-207. 1995.

5. Frey, M. I., R. P. Hanson, and D. P. Anderson. A medium for the isolation of avian mycoplasmas. Am. J. Vet. Res. 29:2163-2171. 1968.

6. Gromeier, M., E. Wimmer, and A. E. Gorbalenya. Genetics, pathogenesis and evolution of picornaviruses. In: Origin and evolution of viruses. E. Domingo, R. Webster, and J. Holland, eds. Academic Press, San Diego, CA. pp. 287-343. 1999

7. Guo, Y. P., and W. S. Pan. Preliminary identifications of the duck hepatitis virus serotypes isolated in Beijing, China. J. Vet. Med. 10:2-3. 1984.

8. Hall, T. A. BioEdit: a user-friendly biological sequence alignment editor and analysis program for Windows 95/98/NT. Nucleic Acid Symp. Ser. 41:95-98. 1999.

9. Hwang, J. Duck hepatitis virus-neutralization in chicken embryo. Am. J. Vet. Res. 30:861-864. 1969.

10. Kim, M. C., Y. K. Kwon, S. J. Joh, A. M. Lindberg, J. H. Kwon, J. H. Kim, and S. J. Kim. Molecular analysis of duck hepatitis virus type 1 reveals a novel lineage close to the genus Parechovirus in the family Picornaviridae. J. Gen. Virol. 87:3307-3316. 2006.

11. Kwon, H. J., S. H. Cho, Y. J. Ahn, S. H. Seo, K. S. Choi, and S. J. Kim. Molecular epidemiology of Newcastle disease in Republic of Korea. Vet. Microbiol. 95:39-48. 2002.

12. Lee, C. W., C. S. Song, Y. J. Lee, I. P. Mo, M. Garcia, D. L. Suarz, and S. J. Kim. Sequence analysis of the hemagglutinin gene of H9N2 
Korean avian influenza viruses and assessment of the pathogenic potential of isolate MS96. Avian Dis. 44:527-535. 2000.

13. Lee, S. K., H. W. Sung, and H. M. Kwon. S1 glycoprotein gene analysis of infectious bronchitis viruses isolated in Korea. Arch. Virol. 149:481-494. 2004.

14. Levine, P. P., and J. Fabricant. A hitherto-undescribed virus disease of ducks in North America. Cornell Vet. 40:71-86. 1950.

15. Maiboroda, A. D. Formation of duck hepatitis virus in culture cells. Veterinariya 8:50-52. 1972.

16. Mansy, M. S., M. S. E. Ashour, and M. I. Khan. Development of species-specific polymerase chain reaction (PCR) technique for Proteus mirabilis. Mol. Cell Probes 13:133-140. 1999.

17. Murty, D. K., and L. E. Hanson. A modified microgel diffusion method and its application in the study of the virus of duck hepatitis. Am. J. Vet. Res. 22:274-278. 1961.

18. Nascimento, E. R., R. Yamamoto, and M. I. Khan. Mycoplasma gallisepticum F-vaccine strain-specific polymerase chain reaction. Avian Dis. 37:203-211. 1993.

19. Nguyen, A. V., M. I. Khan, and Z. Lu. Amplification of Salmonella chromosomal DNA using polymerase chain reaction. Avian Dis. 38: 119-126. 1994.

20. Oberste, M. S., K. Maher, D. R. Kilpatrick, and M. A. Pallansch. Molecular evolution of the human enteroviruses: correlation of serotype with VP1 sequence and application to picornavirus classification. J. Virol. 73:1941-1948. 1999.

21. Park, N. Y. Occurrence of duck virus hepatitis in Korea. Korea J. Vet. Res. 25:171-174. 1985.

22. Pöyry, T., L. Kinnunen, T. Hyypiä, B. Brown, C. Horsnell, T. Hovi, and G. Stanway. Genetic and phylogenetic clustering of enteroviruses. J. Gen. Virol. 77:1699-1717. 1996.

23. Reuss, U. Virusbiologische untersuchungen bei der Entenhepatitis. Zentralbl. Veterinaermed. 6:209-248. 1959.

24. Rodrigo, M. J., and J. Dopazo. Evolutionary analysis of the picornavirus family. J. Mol. Evol. 40:362-371. 1995.
25. Stram, Y., R. Meir, T. Molad, R. Blumenkranz, M. Malkinson, and Y. Weisman. Applications of the polymerase chain reaction to detect infectious bursal disease virus in naturally infected chickens. Avian Dis. 38:879-884. 1994.

26. Tauraso, N. M., G. E. Coghill, and M. J. Klutch. Properties of the attenuated vaccine strain of duck hepatitis virus. Avian Dis. 13:321-329. 1969.

27. Vertinskii, K. I., B. F. Bessarabov, A. N. Kurilenko, A. P. Strelnikov, and P. M. Makhno. Pathogenesis and diagnosis of duck viral hepatitis. Veterinariya 7:27-30. 1968.

28. Wildy, P. Classification and nomenclature of viruses. Monogr. Virol. 5:1-118. 1971 .

29. Woolcock, P. R. Duck hepatitis, In: Disease of poultry, 11th ed. Y. M. Saif, H. J. Barnes, J. R. Glisson, A. M. Fadly, L. R. McDougald, and D. E. Swayne, eds. Iowa State University Press, Ames, IA. pp. 343-354. 2003.

30. Woolcock, P. R., W. S. K. Chalmers, and D. Davis. A plaque assay for duck hepatitis virus. Avian Pathol. 11:607-610. 1982.

31. Xie, Z., A. A. Fadl, T. Girshick, and M. I. Khan. Detection of avian adenovirus by polymerase chain reaction. Avian Dis. 43:98-105. 1999.

32. Xie, Z., M. I. Khan, T. Girshick, and Z. Xie. Reverse transcriptasepolymerase chain reaction to detect avian encephalomyelitis virus. Avian Dis. 49:227-230. 2005.

33. Zaho, X., M. R. Phillips, G. Li, and A. Zhong. Studies on the detection of antibody to duck hepatitis virus by enzyme-linked immunosorbent assay. Avian Dis. 35:778-782. 1991.

\section{ACKNOWLEDGMENTS}

We thank Hyuk-Man Kwon for propagation of DHV-1 samples and other viruses. This work was supported financially by the National Veterinary Research and Quarantine Service, Ministry of Agriculture and Forestry, Republic of Korea. 